\title{
Genesis of accountability and its impact on accounting
}

\author{
Cordelia Onyinyechi Omodero ${ }^{1}$ \\ Clifford University Owerrinta, Abia State, Nigeria ${ }^{1}$ \\ Corresponding author email: cordeliaomodero@yahoo.com
}

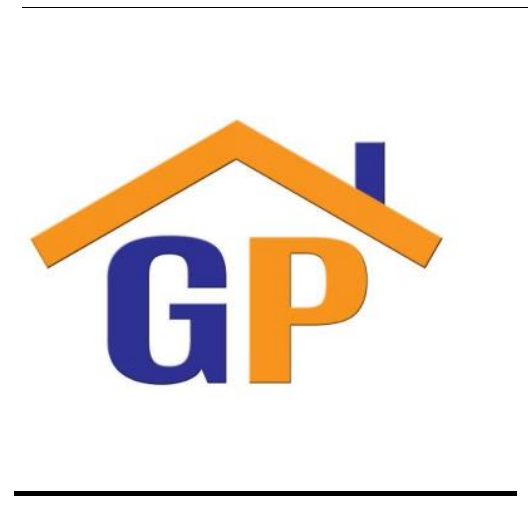

Article History

Received on 15 October 2019

$1^{\text {st }}$ Revision on 15 October 2019

$2^{\text {nd }}$ Revision on 16 October 2019

Accepted on 22 October 2019

\begin{abstract}
Purpose: This study examines the genesis of accountability: a global view. The concept of accountability has been viewed from various disciplinary lenses in order to develop an integrated understanding of the term. Special attention is devoted to principal-agent perspectives from political science and economics.
\end{abstract}

Research methodology: An integrated framework is developed, based on four central observations. (1) Accountability is relational in nature and is constructed through inter- and intra-organizational relationships. (2) Accountability is complicated by the dual role of nonprofits as both principals and agents in their relationships with other actors. (3) Characteristics of accountability necessarily vary with the type of nonprofit organization being examined. (4) Accountability operates through external as well as internal processes, such that an emphasis on external oversight and control misses other dimensions of accountability essential to nonprofit organizations.

Results: The study finds that the time has come for individuals, organizations, stakeholders, establishments, institutions and governments to focus on reporting on their programme results, such as inventory take result and product performance result.

Limitation: Paucity of data and empirical works were the major restrictions to this study.

Contribution: Thus, being clear about intentions, measuring and understanding results, and making adjustments where necessary, would help assure taxpayers/stakeholders that their money is being spent wisely. A focus on results would also help to ensure that limited public resources are being applied in a way that provides the most value to all concerned.

Keywords: Accountability, Genesis, Performance, Responsibility, Types, Assessment, Global

How to cite: Omodero, C. O. (2019). Genesis of accountability and its impact on accounting. International Journal of Financial, Accounting, and Management, 1(1), 47-55. https://doi.org/10.35912/ijfam.v1i1.78

\section{Introduction}

Accountability is an often-used word, yet the concept of accountability is not easily understood. When people hear the word accountability, they know that it means something important, but that's about as far as it goes. Subsequently, because they don't grasp the concept of accountability, they don't know how to (and can't) achieve it. Often, the word responsibility is used in conjunction with the word accountability. When hearing the word accountability, many people immediately equate it with 
responsibility and see the two as being the same. However, (in our opinion) they are not. For example, one quoted author points out the difference, noting that, responsibility is the obligation to perform. This helps employee to understand the objectives of organization which are vital in determining whether or not the organization will succeed (Yuliansyah, 2016). Accountability is the liability one assumes for ensuring that an obligation to perform - a responsibility-is fulfilled" (Frost, 1998). Another key word used when discussing accountability is authority. Distinguishing the difference between it and responsibility is important to understanding the concept of accountability. Authority is the right to act without prior approval from higher management and without challenge from managing peers (Frost, 1998). Authority is assigned. On the other hand, responsibility is delegated. In all of the available literature on the subject of accountability, no common definition or view of accountability can be found. This lack of commonality is due partly to the fact that the concept of accountability - especially in the governmental setting - is just coming to the forefront.

The purpose of this paper is to examine the genesis of accountability in global perspectives. Accordingly, the following specific objectives have been pursued in this paper:

(a) To explore the genesis and concept of accountability

(b) To examine the types of accountability under discussion

(c) To assess accountability relations, arrangements and systems

In order to achieve the above objectives the following research questions have been raised for discussions in this study:

(i) What is genesis and concept of accountability?

(ii) What are types of accountability being discussed?

(iii) How should we assess accountability relations, arrangements and systems?

\section{Literature review and hypotheses development}

\subsection{The genesis and concept of accountability}

The word 'accountability' is Anglo-Norman, not Anglo-Saxon, in origin. Historically and semantically, it is closely related to accounting, in its literal sense of bookkeeping. According to Dubnick (2002), the roots of the contemporary concept can be traced to the reign of William I, in the decades after the 1066 Norman conquest of England. In 1085 William required all the property holders in his realm to render account of what they possessed. These possessions were assessed and listed by royal agents in the so-called Domesday Books. This census was not held for taxation purposes alone; it also served as a means to establish the foundations of royal governance. The Domesday Books listed what was in the king's realm; moreover, the landowners were all required to swear oaths of fealty to the crown. By the early twelfth century, this had evolved into a highly centralized administrative kingship that was ruled through centralized auditing and semi-annual account-giving. In the centuries since the reign of William I of England, accountability has slowly wrestled free from its etymological bondage with accounting. In contemporary political discourse, 'accountability' and 'accountable' no longer convey a stuffy image of bookkeeping and financial administration, but they hold strong promises of fair and equitable governance. Moreover, the accounting relationship has almost completely reversed. 'Accountability' does not refer to sovereigns holding their subjects to account, but to the reverse, it is the authorities themselves who are being held accountable by their citizens.

Accountability stems from Late Latin accomptare (to account), a prefixed form of computare (to calculate), which in turn derived from putare (to reckon), (Ezzamel, 1997). While the word itself does not appear in English until its use in 13th century Norman England, (Seidman, 2005). The concept of account-giving has ancient roots in record keeping activities related to governance and money-lending systems that first developed in Ancient Egypt, Israel, Babylon, Greece, and later, Rome, (Walzer, 1994; Urch, 1929; Roberts, 1982; Plescia, 2001; Scott \& Lyman, 1968). Accountability involves either the expectation or assumption of account-giving behaviour. The study of account giving as a sociological act was articulated in a 1968 article on "Accounts" by Marvin Scott and Stanford Lyman, (Scott \& Lyman, 1968). Also, it can be traced as well to Austin's (1956) essay "A Plea for Excuses", in which he used excuse-making as an example of speech acts. 
Communications scholars have extended this work through the examination of strategic uses of excuses, justifications, rationalizations, apologies and other forms of account giving behaviour by individuals and corporations, and Plescia, (2001) has applied experimental design techniques to explore how individuals behave under various scenarios and situations that demand accountability. Since the late twentieth century, the Anglo-Saxon world in particular has witnessed a transformation of the traditional bookkeeping function in public administration into a much broader form of public accountability (Harlow, 2002). This broad shift from financial accounting to public accountability ran parallel to the introduction of New Public Management by the Thatchergovernment in the United Kingdom and to the Reinventing Government reforms initiated by the Clinton-Gore administration in the United States. Both reforms introduced a range of private sector management styles and instruments into the public sector (Pollitt \& Bouckaert, 2005), including contract management both within and outside the public sector, the use of performance indicators and benchmarks to evaluate and compare the effectiveness and efficiency of public agencies, to name but a few. Most of these instruments require extensive auditing to be effective.

This shift from financial accounting to performance auditing and public accountability can also be observed on the European continent, although the speed and scope differs. Countries with a strong tradition of administrative law and a strong Rechtsstaat, such as France, Germany and Italy, have, on average, been less vigorous in adopting these more managerially oriented styles of governance. Countries like the Netherlands, Sweden, and Finland are intermediate cases (Pollitt \& Summer, 1997; Pollitt \& Bouckaert, 2005). The emancipation of 'accountability' from its bookkeeping origins is therefore originally an Anglo-American phenomenon - if only because other languages, such as French, Portuguese, Spanish, German, Dutch, or Japanese, have no exact equivalent and do not (yet) distinguish semantically between 'responsibility' and 'accountability' (Mulgan, 2000; Harlow, 2002; Dubnick, 2002). Accountability is a multidimensional concept and often a key enabler of success . . . To truly work, accountability has to be shared by managers and employees; further, your organization as a whole must be accountable to the customer and stakeholder (Dubnick \& Barbara, 1993; Dubnick, 1998).

Accountability is an often used word, yet the concept of accountability is not easily understood. When people hear the word accountability, they know that it means something important, but that's about as far as it goes. Subsequently, because they don't grasp the concept of accountability, they don't know how to (and can't) achieve it. This section provides several views on accountability, gives a working definition of accountability, presents its key aspects, and identifies the levels of accountability. By the time you finish reading this section, you should have a better understanding of the concept of accountability. Accountability is one of those golden concepts that no one can be against. It is increasingly used in political discourse and policy documents because it conveys an image of transparency and trustworthiness. However, its evocative powers make it also a very elusive concept because it can mean many different things to different people, as anyone studying accountability will soon discover. This paper nevertheless tries to develop an analytical framework for the empirical study of accountability arrangements in the public domain. It starts from a narrow, relational definition of accountability and distinguishes a number of indicators that can be used to identify and classify accountability arrangements. Furthermore, it develops three perspectives to assess and evaluate accountability arrangements in the public domain. In all of the available literature on the subject of accountability, no common definition or view of accountability can be found. This lack of commonality is due partly to the fact that the concept of accountabilityespecially in the governmental setting - is just coming to the forefront. Accountability may be defined as a clearly recognized employee responsibility for the (official) manner of an identified program assignment where performance is assessed through the use of well-known standards.

\subsection{Types of accountability under discussion}

Accountability comes in many guises. Public institutions are frequently required to account for their conduct to various forums in a variety of ways. Political accountability: elected representatives, political parties, voters, media Political accountability is an extremely important type of public accountability within democracies. Here, accountability is exercised along the chain of principal-agent relationships (Strom, 2000). Voters delegate their sovereignty to popular 
representatives, who in turn, at least in parliamentary democracies, delegate the majority of their authorities to a cabinet of ministers. The ministers subsequently delegate many of their authorities to their civil servants or to various, more or less independent, administrative bodies. The mechanism of political accountability operates precisely in the opposite direction to that of delegation. In parliamentary systems with ministerial accountability, such as the United Kingdom, the Netherlands and Germany, public servants and their organisations are accountable to their minister, who must render political account to parliament (Scott, 2000; Flinders, 2001; Strom, Müller \& Bergman, 2003).

Legal accountability: courts In most western countries, legal accountability is of increasing importance to public institutions as a result of the growing formalisation of social relations (Friedman, 1985; Behn, 2001; Dubnick, 2003), or because of the greater trust which is placed in courts than in parliaments (Harlow, 2002). These can be the 'ordinary' civil courts, as in Britain, or also specialised administrative courts, as in France, Belgium, and The Netherlands (Harlow, 2002). In some spectacular cases of administrative deviance, such as the affaire du sang (the HIV contaminated blood products) in France or the Tangentopoli prosecutions in Italy, public officials have even been summoned before penal courts.

Administrative: auditors, inspectors, and controllers Next to the courts, a wide range of quasilegal forums exercising independent and external administrative and financial supervision and control, has been established in the past decades - some even speak of an 'audit explosion' (Power 1994). These new administrative forums vary from European, national, or local ombudsmen and audit offices, to independent supervisory authorities, inspector generals, anti-fraud offices, and chartered accountants. Professional accountability: professional peers. Many public managers are, apart from being general managers, professionals in a more technical sense. They have been trained as engineers, doctors, veterinarians, teachers, or police officers (Abbot, 1988; Freidson, 2001). This may imply accountability relationships with professional associations and disciplinary tribunals.

Social accountability: interest groups, charities and other stakeholders In reaction to a perceived lack of trust in government, there is an urge in many western democracies for more direct and explicit accountability relations between public agencies on the one hand and clients, citizens and civil society on the other hand (McCandless, 2001). Influenced by the debate on corporate social responsibility and corporate governance in business, more attention has been being paid to the role of NGOs, interest groups and customers or clients as relevant 'stakeholders' not only in determining policy, but also in rendering account (European Commission, 2001; Algemene Rekenkamer, 2004). Corporate accountability: the organisation as actor. Many public organisations are corporate bodies with an independent legal status. They can operate as unitary actors and can be held accountable accordingly. Most western countries accept corporate liabilities in civil, administrative, and even criminal law. Public organisations are usually included in these corporate liabilities, with the exception of criminal liability. Most European countries acknowledge penal immunities for all public bodies. Some, such as the UK, France, and The Netherlands, accept criminal liabilities for local public bodies, but not for the organs of the state. Only Norway, Denmark, and Ireland accept criminal liability of both central and local government (Roef, 2001). Legal and administrative forums often follow this corporate accountability strategy.

Hierarchical accountability: One for all This is the official venue for public accountability in most public organisations, and with regard to most types of accountability relationships, with the exception of professional accountability. It is particularly dominant in political accountability relations, for example in the Westminster system of ministerial responsibility. Underlying hierarchical strategies of accountability is a pyramidal image of complex organisations. Processes of calling to account start at the top. Collective accountability: All for one Public organisations are collectives of individual officials. Theoretically, a forum could therefore also apply a collective strategy of accountability and pick any member of the organisation and hold it personally accountable for the conduct of the organisation as a whole, by virtue of the fact that it is a member of the organisation. This makes quick work of the practical sides of the problem of many hands. In the case of organisational misconduct, every member of the organisation can be held accountable. 
Individual accountability: Each for himself. During the judgement phase, which can involve the imposition of sanctions, hierarchical and collective accountability strategies often run up against moral objections, as a proportional relation between crime and punishment is by no means always evident. An individual accountability in which each individual official is held proportionately liable for his personal contribution to the infamous conduct of the organisation, is from a moral standpoint a far more adequate strategy. Under this approach, each individual is judged on the basis of his actual contribution instead of on the basis of his formal position.

\section{Research methodology}

\section{Assessing Accountability Relations, Arrangements and Systems}

An altogether different exercise is the assessment of the adequacy of a particular accountability arrangement or of a complete accountability regime to which a particular agency or sector is subject. Here we leave the realm of empirical description and enter the world of evaluation and, ultimately, prescription. This is much more a matter of degree and these assessments follow the logic of more-or-less (Sartori, 1979). This evaluation can proceed at least two levels. First of all, one could undertake a more internal, procedural evaluation of the propriety of a particular accountability mechanism or of a specific, concrete accountability process. This could be called procedural or internal adequacy. Secondly, one could evaluate accountability arrangement or regimes on a more systemic level and focus on the external effects of the accountability processes. This could be called systemic or external adequacy. In this case the evaluation is based on the functions that accountability arrangements fulfil in political and administrative systems. I will discuss both types of assessments.

The internal evaluative perspective sees at the quality of a particular accountability process itself: does the procedure comply with the minimum due requirements of an accountability procedure? In a procedure-oriented analysis of this kind, the following questions come to mind: Is there (any guarantee for) an adequate and proper provision of information by the actor? Does the forum receive timely and sufficient information from the actor in order to enable a well-founded judgement of his conduct to be made? Carefully managed embedded press conferences, such as those held by the American military during the invasion of Iraq in 2003 may, in the nominal sense, represent a form of public accountability. However, the information provided was often scanty in the extreme, or biased in favour of the authorities, and there was little room for inquisitive probing by journalists, thus disqualifying this as good accountability.

Next, there is the question of due process during the debate about the actor's conduct. Is the forum prepared to allow the actor sufficient opportunity to explain and to justify his conduct, or does it immediately pass judgement? Has it been made clear to the actor what the standards are in relation to which his conduct will be judged? An example of public accountability arrangements where these requirements were violently trampled upon were the forced public accountability procedures in the former communist dictatorships, as described e.g. by Tonkens, (2003), in which dissidents were publicly forced to present themselves as class enemies. Even in the democracies of the western world, instances of public accountability occur, such as political accountability to the media, in which the principle of hearing and being heard is wantonly disregarded. The third question that arises is whether the forum is able to pass sound judgement. Is the forum sufficiently independent of the actor or is the actor in actual fact the judge in his own case? This can be an important factor in the case of self-appointed panels and visitation committees. Yet the opposite can also arise, as in the case of a biased forum. Is the forum sufficiently neutral or has it exhibited a strong bias toward the actor? Do the facts warrant the judgement? Is the sanction adequate in the light of the judgement?

This series of questions, respectively about the quality of the provision of information by the actor, the quality of the procedure, and the quality of the forum's judgement, afford a framework for a normative analysis of accountability procedures. These might offer a basis for the development of a coherent system of requirements for appropriate and proper accountability, the principles of good accountability. The key question is obviously what the actual effects are of the various types of accountability and how to judge these effects. At this level, inadequacies can either 
take the form of accountability deficits: a lack of sufficient accountability arrangements; or of accountability excesses: dysfunctional, negative effects of the accumulation of a range of accountability mechanisms. The former inadequacy can be hypothesized for various aspects of European governance (Arnull \& Wincott, 2002; Harlow, 2002; Fisher, 2004), the latter is increasingly reported by executive agencies and public managers (Anechiarico \& Jacobs, 1996; Power, 1994; Behn, 2001; Halachmi, 2002; Tonkens 2003). The questions remains however: how do we establish whether these different sorts of inadequacies do exist?

For an institutionalised ideal that is so broadly supported and applied, there are very few references to be found in the literature that could lead to such an evaluation being performed, let alone any reports on systematic comparative research conducted in this area. Authors such as Behn (2001), Halachmi (2002) and Mulgan (2003) offer discussions of the many dilemmas and design problems in the structure of accountability arrangements, but the underlying normative questions what is the purpose of public accountability in a constitutional democratic state and what are the evaluation principles for accountability arrangements ensuing from this? - tend to be glossed over in these contributions. So why is public accountability important? What is the purpose of the various different forms distinguished in this paper? In the academic literature and in policy publications about public accountability, three answers recur, albeit implicitly, time and again. Public accountability is important to provide a democratic means to monitor and control government conduct, for preventing the development of concentrations of power, and to enhance the learning capacity and effectiveness of public administration (Aucoin \& Heintzman, 2000). Each of these three answers yields a separate theoretical perspective on the rationale behind public accountability and a separate perspective for the assessment of accountability relations.

The three perspectives outlined above offer more systematic frameworks to evaluate the effects of accountability arrangements. The question central to the democratic perspective is whether the accountability arrangement adds to the possibilities open to voter, parliament or other representative bodies to control the executive power. Thus viewed, the main concern is that the accountability arrangements yield relevant information about the conduct of the government. The major issue in assessing accountability arrangements from this perspective is whether they help to overcome agency problems, such as moral hazard (Strom 2003): do these accountability arrangements help to provide political principals with sufficient information about the behaviour of their agents and do they offer enough incentives to agents to commit themselves to the agenda's of their democratically elected principals?

From a constitutional perspective, the key question is whether the arrangement contributes to the prevention of corruption and the abuse of powers. This standpoint demands that public accountability forums be visible, tangible and powerful, in order to be able to withstand both the inherent tendency of those in public office to dexterously evade control and the autonomous expansion of power of the all-encompassing bureaucracy. The major issue from this perspective is whether accountability arrangements offer enough incentives for officials and agencies to refrain from abuse of authority. Does the accountability forum have enough inquisitive powers to reveal corruption or mismanagement, are the available sanctions strong enough to have preventive effects? The cybernetic perspective obviously focuses on the question of whether the arrangement enhances the learning capacity and effectiveness of the public administration. This viewpoint will judge accountability arrangements and other feedback mechanisms to be successful if they generate feedback information and stimulate elite groups to reflect and to debate about the significance of this information with others (Tonkens, 2003). The crucial questions from this perspective are whether the accountability arrangements offer sufficient feedback, but also the right incentives, to officials and agencies to reflect upon their policies and procedures and to improve upon them.

\section{Results and discussions}

This paper has tried to get to grips with the appealing but elusive concept of accountability by asking three types of questions, thus providing three types of building blocks for such an evaluation. First a conceptual one: what is genesis and concept of accountability? Accountability is often used in a very broad sense, as a synonym for a variety of evaluative, but essentially contested concepts, such as responsiveness, responsibility and effectiveness. In this paper the concept of accountability is taken in a much more narrow sense: a relationship between an actor and a forum, in which the actor has an 
obligation to explain and to justify his or her conduct, the forum can pose questions and pass judgment, and the actor can be sanctioned. This implies that the focus of accountability research should be on ex post facto processes in governance and not on ex ante inputs.

The second question is an analytical one: what are types of accountability being discussed? On the basis of the narrow definition of accountability, a series of dimensions of accountability have been discerned, that can be used in the description of the various accountability relations and arrangements that can be found in the different domains of European governance. Taken together, these two building blocks provide a descriptive framework for more systematic mapping exercises: are the various institutions of the European Union subjected to accountability relations at all, and, if so, how can we classify these accountability relations? The third question is an altogether different, evaluative question: how should we assess accountability relations, arrangements and systems? Three perspectives have been provided for the assessment of accountability relations: a democratic, a constitutional, and a cybernetic perspective. Each of these three perspectives may render different types of accountability deficits.

Conclusively, this study offers four broad observations about accountability in global perspective. First, accountability is a relational concept. It does not stand objectively apart from organizational relationships, since the demands for accountability and the mechanisms used to achieve it are constructed by those very relationships. Second, organizations can function as both principals and agents in each of these relationships. Moreover, the dominant direction of a relationship is determined by the presence and use of accountability mechanisms to enforce it. Third, the characteristics of accountability necessarily vary with organization type. Accountability to clients appears to be weak in these organizations, at least in comparison to accountability to funders and regulators.

\section{Conclusion}

Finally, accountability is both external and internal. It may be defined as the means through which individuals and organizations are held externally to account for their actions (for example, through legal obligations and explicit reporting and disclosure requirements) and as the means by which they take internal responsibility for continuously shaping and scrutinizing organizational mission, goals, and performance (such as through self-evaluations, participatory decision processes, and the systematic linking of organizational values to conduct). Although external oversight is necessary, no amount of it will inculcate a felt responsibility. An integrated perspective recognizes this multidimensional and relational nature of accountability, rather than reducing it to a concept enforced through oversight and regulatory mechanisms.

\section{Acknowledgement}

The author thanks the editors and anonymous reviewers of the International Journal of Financial, Accounting, and Management (IJF AM) for adding so much value to this paper. The first phase of this work is available online at Social Science Research Network: http://ssrn.com/abstract=2633982.

\section{References}

Abbott, A. (1988). The system of professions: an essay on the division of expert labour. Chicago: University of Chicago Press..

Algemene Rekenkamer (2004). Achtergrondstudie brede publieke verantwoording bij RWT's en ZBO's, Den Haag: Algemene Rekenkamer.

Anechiarico, F. \& Jacobs, J. B. (1996). The pursuit of absolute integrity: how corruption control makes government ineffective. Chicago: University of Chicago Press.

Arnull, A. \& Wincott, D. (2001). Accountability and legitimacy in the European Union. New York \& Oxford: OUP.

Aucoin, P. \& Heintzman, R. (2000). The dialectics of accountability for performance in public management reform. International Review of Administrative Sciences, 66: 45-55. 
Austin, J.L. (1956-7). A plea for excuses. Proceedings of the Aristotelian society. Reprinted in J. O. Urmson \& G. J. Warnock, eds., 1979, J. L. Austin: Philosophical Papers, 3rd edition. Oxford: Clarendon Press.

Behn, R. D. (2001). Rethinking democratic accountability. Washington, D.C.: Brookings Institution Press.

Dubnick, M. J. \& Barbara S. R. (1993). Accountability and the centrality of expectations in American public administration. Research in Public Administration, Volume 2: 37-78.

Dubnick, M. J. (1998). Clarifying accountability: an ethical theory framework. in Charles Sampford, Noel Preston and C. A. Bois. Public sector ethics: finding and implementing values. Leichhardt, NSW, Australia. The Federation Press/Routledge.

Dubnick, M. J. (2002). Seeking salvation for accountability. Paper presented at the 2002 Annual Meeting of the American Political Science Association, Boston.

Dubnick, M. J. (2003). Accountability and the promise of performance. Paper presented at the 2003 Annual Meeting of the American Political Science Association, Philadelphia.

European Commission (2001). European governance. A White paper, Brussels.

Ezzamel, M. (1997). Accounting, control and accountability: preliminary evidence from ancient Egypt. Critical Perspectives on Accounting 8 (6), 563-601. Doi: 10.1006/cpac.1997.0123.

Fisher, E. (2004). The European Union in the age of accountability. Oxford Journal of Legal Studies, 24(3), 495-515.

Flinders, M. (2001). The politics of accountability in the modern state. Ashgate, 2001, pp. 456.

Friedman, L. M. (1985). Total justice. New York: Russel Sage.

Freidson, E. (2001). Professionalism: the third logic. Cambridge: Polity Press.

Frost, A. (1998). Restoring faith in government: transparency reform in the United States... An analytical framework. Public Law 467.

Halachmi, A. (2002a). Performance measurement: a look at some possible dysfunctions. Work Study, 51(5) 230-239.

Halachmi, A. (2002b). Performance measurement, accountability and improved performance. Public Performance and Management Review, 25(4), 370-374.

Harlow, C. (2002). Accountability in the European Union. Oxford: Oxford University Press. Hart P. 't , 2001, Verbroken verbindingen: Over de politisering van het verleden en de opkomst van een inquisitiedemocratie, Amsterdam: De Balie.

McCandless, H. E. (2001). A Citizen's Guide to public accountability: changing the relationship between citizens and authorities. Victoria B.C.: Trafford.

Mulgan, R. (2000). Comparing accountability in the public and private sector. Australian Journal of Public Administration, 59(1), 87-97.

Mulgan, R. (2000). Accountability: An ever expanding concept? Public Administration, 78, 555.

Mulgan, R. (2003). Holding power to account: accountability in modern democracies. Basingstoke: Pelgrave.

Plescia, J. (2001). Judicial accountability and immunity in Roman law. The American Journal of Legal History, Vol. 45, No. 1, 51-70. Doi: 10.2307/3185349. JSTOR 3185349

Pollitt, C. \& Summer, H. (1997). Reflexive watchdogs? How supreme audit institutions account for themselves. Public Administration, 75(2), 313-336.

Pollitt, C. \& Bouckaert, G. (2005). Public management reform: a comparative analysis. Second Edition, Oxford: OUP.

Power, M. (1994). The audit explosion. London: Demos.

Roberts, J. (1982). Accountability in Athenian government. Madison, WI: University of Wisconsin Press.

Roef, D. (2001). Strafbare overheden: een rechtsvergelijkende studie naar de strafrechtelijke aansprakelijkheid van overheden voor milieuverstoring. Antwerpen: Intersentia. 
Sartori, G. (1970). Concept malformation in comparative politics. American Political Science Review, LXIV, 4, 1033-1053.

Scott, C. (2000). Accountability in the regulatory state. Journal of Law and Society, 27(1), 38-60.

Scott, C. \& Lyman, (1968). Accounts. American Sociological Review, 33 (1), 46-62. Doi:10.2307/2092239. JSTOR 2092239.PMID 5644339.

Seidman, G. I. (2005). The origins of accountability: everything I know about the sovereign's immunity, I learned from King Henry III. St. Louis University Law Journal 49(2), 393- 480.

Strom, K. (2000). Delegation and accountability in parliamentary democracies. European Journal of Political Research, 37, 261-289.

Strom, K. (2003). Parliamentary democracy and delegation. In: K. Strom et al.(eds.), Delegation And accountability in Parliamentary Democracies. Oxford: OUP: 55-106.

Strom, K., Muller, W.C. \& Bergman, T. (2003). Delegation and accountability in parliamentary democracies. Oxford: OUP.

Tonkens, E. (2003). Mondige burgers, getemde professionals: marktwerking, vraagsturing en professionaliteit in de publieke sector. Utrecht: NIZW.

Urch, E. J. (1929). The law code of Hammurabi. American Bar Association Journal 15 (7), 437-441.

Walzer, M. (1994). The legal codes of ancient Israel. In ian shapiro. The rule of law. NY: New York University Press. pp. 101-119.

Yuliansyah, Yuliansyah. (2016). Attributes influencing strategic alignment in the service sector: an Indonesian banking sector case study. International Journal of Business, Economics and Management. 2. 34-48. 10.18488/journal.62/2015.2.2/68.2.34.48. 